\title{
Deer Exclusion Changes Vegetation Structure and Hunting Guilds of Spiders, but Not Multitrophic Understory Biodiversity
}

\author{
Roman Bucher ${ }^{1, *(D)}$, Jonas Rochlitz ${ }^{1,2}$, Nathalie Wegner ${ }^{1}$, Anna Heiß ${ }^{1}$, Alexander Grebe ${ }^{1}$, Dana G. Schabo ${ }^{1}$ and \\ Nina Farwig 1 \\ 1 Department of Biology, Conservation Ecology, University of Marburg, Karl-von-Frisch-Str. 8, \\ 35043 Marburg, Germany; jonas.rochlitz@uni-muenster.de (J.R.); nathalie_wegner@gmx.de (N.W.); \\ anna.heiss@gmx.de (A.H.); Axelgrebe@web.de (A.G.); dana.schabo@staff.uni-marburg.de (D.G.S.); \\ farwig@staff.uni-marburg.de (N.F.) \\ 2 Centre for Biodiversity Monitoring, Zoological Research Museum Alexander Koenig, Adenauerallee 160, \\ 53113 Bonn, Germany \\ * Correspondence: bucher@uni-marburg.de; Tel.: +49-(0)6421-282-3472
}

check for updates

Citation: Bucher, R.; Rochlitz, J.; Wegner, N.; Heiß, A.; Grebe, A.; Schabo, D.G.; Farwig, N. Deer Exclusion Changes Vegetation Structure and Hunting Guilds of Spiders, but Not Multitrophic Understory Biodiversity. Diversity 2021, 13, 25. https://doi.org/ $10.3390 / \mathrm{d} 13010025$

Received: 30 November 2020 Accepted: 8 January 2021

Published: 12 January 2021

Publisher's Note: MDPI stays neutral with regard to jurisdictional clai$\mathrm{ms}$ in published maps and institutional affiliations.

Copyright: (C) 2021 by the authors. Licensee MDPI, Basel, Switzerland. This article is an open access article distributed under the terms and conditions of the Creative Commons Attribution (CC BY) license (https:// creativecommons.org/licenses/by/ $4.0 /)$.

\begin{abstract}
Ungulate herbivores modify plant community compositions, which can modulate biodiversity at higher trophic levels. However, these cascading effects on herbivorous and predatory arthropods in forest ecosystems remain poorly understood. We compared plant and arthropod communities between fenced exclosures and unfenced control plots in a permanent forest in Germany. After five years of deer exclusion, we quantified plant diversity and vegetation structure as well as the diversity of insects and spiders in 32 pair-wise plots. In addition, we compared spider communities with respect to different hunting guilds because they are expected to have different requirements for vegetation structure. Although we did not find differences in plant communities, vegetation height and heterogeneity were higher in exclosures compared to control plots. The diversity of insects and spiders was not affected by deer presence. However, the abundance of sheet-web weavers and ambush hunters was lower in exclosures whereas ground hunters were more common in exclosure plots. Structural changes in the vegetation changed predator hunting guilds even though mere abundance and biodiversity indices were not affected. We therefore suggest that monitoring of vegetation structure and associated functional groups seems more sensitive to assess the impact of ungulate herbivores compared to taxonomic metrics.
\end{abstract}

Keywords: arthropod diversity; functional groups; trophic cascades; ungulate herbivores; browsing; deer exclusion experiments; Araneae

\section{Introduction}

During the last century, ungulate species have increased in abundance and distribution in various European countries and are still increasing due to the loss of native predators, changes in land use, and moderate winter conditions [1-3]. Presently, many large ungulate species are actively hunted for socio-cultural and economic reasons [4,5]. In particular, browsing and bark stripping of trees by ungulate herbivores cause financial damage to forestry [6]. Due to this economic interest, studies on the impact of ungulate herbivores in forest ecosystems mainly focused on tree species regeneration. However, also the impact of herbivores on understory plant species diversity has been studied (reviewed by [7,8]).

Large herbivore ungulates such as red and roe deer affect understory plant diversity in various ways $[6,9,10]$ : First, the consumption of leaves, stems, flowers, and fruit directly affects survival, growth, and reproduction of individual plants [6,11]. Many ungulate species feed selectively on the vegetation with some plant species being preferred while other plant species are avoided [4]. This feeding behavior of ungulates at high densities can 
change plant community composition and reduce local plant diversity $[12,13]$. Secondly, ungulate herbivores can lead to a decrease in vegetation height and a loss of structural complexity, as intensive browsing causes dwarf growth or vegetative spread in many plants [14]. At a larger scale, foraging patterns depend on season, predation and hunting risk, microhabitat availability, and the availability of alternative food sources [13,15]. Shifts in plant species composition and vegetation structure can cascade through ecosystems impacting the abundance and diversity of other organisms [16,17].

The effects of large ungulate herbivores on the diversity of organisms at higher trophic levels in forest ecosystems, however, remain unclear $[7,14,18]$. Herbivorous insects, for example, are primary consumers just like deer. Consequently, herbivorous insects compete with large ungulate herbivores for plant biomass [19]. Due to ungulates' and insects' large differences in body size this competition is largely asymmetrical and can reduce the associated insect abundance [20]. In a study on the effects of deer-overabundance on islands, deer presence was associated with a $90 \%$ decline in ground-dwelling invertebrates [21]. In contrast, litter arthropods such as weevils and millipedes tended to benefit from the presence of large herbivore species [22]. In addition, changes in the plant community composition can reduce the availability of host plants for specialized herbivorous insects (Resource Specialization Hypothesis; [23-25]), which in turn can change insect communities and reduce the diversity of herbivorous insects $[9,16,18]$.

At even higher trophic levels, the abundance and diversity of predators can depend on the availability of herbivorous insects as prey. Here, spiders are of particular interest, because they are not only affected by prey availability but also directly depend on vegetation structure [26-28]: Herbivorous insects are an important component of spider's prey [29]. Habitat suitability for spiders has been positively linked to the abundance and availability of suitable insect prey $[30,31]$. Thus, an indirect reduction of prey abundance and diversity via the impact of ungulate herbivores on plants is expected to expand into the predatory guild. In addition, changes in understory vegetation due to browsing modifies the structure of ground and shrub layers [32] and can thus change habitat suitability for spiders. For instance, web-building spiders use the vegetation structure as anchoring points for their webs [33]. Due to different structural requirements, effects of ungulate herbivores on spiders are expected to differ between hunting guilds. Given these complex and contrasting expectations, it remains unclear to which extent ungulate browsing has cascading effects through prey availability and vegetation structure on spiders.

Here, we studied effects of deer exclusion on plant diversity and vegetation structure as well as on herbivorous and predatory arthropod diversity in a permanent forest in Central Germany. To do so, we compared fenced exclosures and unfenced control plots in a forest ecosystem with populations of roe deer (Capreolus capreolus L.) and red deer (Cervus elaphus L.). The deer species were excluded in 2013 to quantify effects of ungulate herbivores on understory biodiversity. In our multi-taxon approach, we focused on cascading effects into higher trophic levels including herbivorous insects and spiders. In addition, we chose spider hunting guilds for a comparison of functional groups because different hunting guilds are expected to respond differently to changes in vegetation structure. We expected (1) a higher plant species richness, a higher vegetation height, and a more heterogenous vegetation in deer exclosures compared to control plots; (2) herbivorous insect and spider abundance, richness, and diversity to be higher in exclosures compared to control plots; (3) spider communities should differ between exclosures and control plots with web-building spiders being more abundant in deer exclosures compared to control plots.

\section{Materials and Methods}

\subsection{Study Area}

Our study sites were located in the Burgwald $\left(50^{\circ} 56^{\prime} \mathrm{N}, 8^{\circ} 49^{\prime} \mathrm{E}\right)$, which is a permanent forest managed by the Hessian administration of state forests (HessenForst) in Central Germany. The local forest management shaped a mixed species stand of an age between 
80 to 120 years with Scots pine (Pinus sylvestris L.), Norway spruce (Picea abies H.KARST) and European beech (Fagus sylvatica L.) dominating the Burgwald forest [34]. Focal trees are selectively harvested (i.e., no clearcutting with extensive tree regeneration). With an area of approximately 20,000 ha, the Burgwald represents one of the largest forests in the federal state of Hesse [35]. In the entire region hunting is managed by federal foresters of HessenForst or private hunters. In 2017, harvest numbers of ruminant hoofed game (including wild boar) first reached 32,000 animals per year on Hessian state forest land. The harvest numbers of roe deer (Capreolus L.) increased over the years, from approximately 11,000 in 2006/2007 to 18,000 in 2016/2017 [36], resulting in a harvest of 8 roe deer per 100 ha (an estimated roe deer density of approximately 20 individuals per $100 \mathrm{ha}$ ). The red deer (Cervus elaphus L.) harvest numbers average around 3000 per year on Hessian state forest land [36]. Red deer densities in the Burgwald area have been estimated to less than 15 individuals per 1000 ha [37].

\subsection{Field Methods}

We selected 32 study sites with two paired plots in the southern part of the Burgwald. The plots were established in 2013 by HessenForst to monitor ungulate browsing in the permanent forest units. A pair of plots included a fenced ungulate exclosure and an unfenced control plot of $64 \mathrm{~m}^{2}$ each at a distance of 5 to $20 \mathrm{~m}$ between the two paired plots. We opted for a pair-wise design to exclude possible confounding factors such as tree density, canopy openness, and microclimatic differences. To prevent ungulate browsing, a $2 \mathrm{~m}$ high lath fence was installed around each exclosure plot. All plots were sampled during two field campaigns, once at the end of May and the end of July 2018 for ten days each. During the first field campaign, we established three randomly selected sampling sub-plots of $4 \mathrm{~m}^{2}$ in each plot. Vegetation height was measured in each sub-plot and vegetation cover was estimated at eight different heights: 5, 10, 20, 40, 80, 120, 160, and $200 \mathrm{~cm}$ in each sub-plot. The Shannon index of vegetation cover at eight different heights was later used as an indicator for vegetation heterogeneity. Within each sub-plot, we determined plant species richness and estimated the cover of each plant species. Plant species richness and plant cover, as an estimate of pseudo-abundance, were used to calculate a Shannon index, referred to as plant diversity. Vegetation and plant diversity data of the three sub-plots were pooled per plot.

Foliage associated insects and spiders were collected using a suction sampler (modified STIHL SH86 leaf blower; Stihl, Waiblingen, Germany). Suction samplers are an effective tool for the quantification of the diversity of invertebrates, such as beetles, true bugs or spiders [38]. We modified the suction sampler's nozzle (15 cm diameter) using a collection net as described by Stewart and Wright [39]. Sampling was done for $60 \mathrm{~s}$ on four randomly selected sub-plots of $0.5 \mathrm{~m}^{2}$ (bottomless plastic barrel, approximately $100 \mathrm{~cm} \times 80 \mathrm{~cm}$ ) within the plots during both field campaigns. After sampling of each sub-plot, we transferred the content to a sorting container (white plastic box, approximately $50 \mathrm{~cm} \times 30 \mathrm{~cm} \times 20 \mathrm{~cm}$ ), where herbivorous insects and spiders were separated from plant material. Insects and spiders were stored in vials containing $70 \%$ ethanol. Insects were determined to the highest taxonomic level possible but at least to the order level. The trophic level of the insects was identified either based on ecological information for the respective taxonomic group and based on the morphology of their mouth parts (leaf chewing mandibles or proboscis to penetrate plant tissue). Herbivorous insects included folivorous, omnivorous-folivorous, omnivorous-phytophagous, and phytophagous feeding guilds. All analyses of herbivorous insects were done at the order level, referred to as insect richness (i.e., number of herbivorous insect orders) and insect diversity (i.e., Shannon index of herbivorous insect orders and abundance). We included juvenile spider individuals in our study, which could be identified to family level to obtain reliable estimates of spider abundance and hunting guilds based on Cardoso et al. [40]. Adult spiders were identified to species level to assess spider species richness and diversity (Shannon index of spider species and abundance). Arthropod data from both field campaigns were pooled per plot. 


\subsection{Data Analysis}

To compare mean vegetation height between exclosures and control plots, we applied a generalized linear mixed model (GLMM) from the lme4 R-package [41] with Poisson error distribution. Model error distribution was chosen based on the quality of the variables (counts vs. numeric) and visual inspection of frequency distribution (normal vs. skewed) following Zuur et al. [42]. We included an observation-level random effect as an intercept for plots [43] to account for overdispersion and models were nested per site (i.e., pair-wise design). Vegetation heterogeneity was compared with a GLMM following Gamma error distribution nested per site. Statistical parameters for the factor treatment (exclosure vs. control) were obtained via maximum likelihood (ML) with Laplace approximation to calculate $\chi^{2}$-values [44].

To compare differences in the abundance of insects, spiders, and spider hunting guilds as well as for the comparison of plant, insect, and spider species richness between deer exclosures and control plots, we applied GLMM's with Poisson error distribution. Models were nested per site and included an observation-level random effect to account for overdispersion. The diversity of plants, insects, and spiders was assessed with a linear mixed model (LMM) nested per site. Statistical parameters were obtained as described above.

Differences in plant and arthropod community composition between exclosures and control plots were assessed with permutational analysis of variances (PERMANOVA) based on an untransformed matrix of species composition and Bray-Curtis dissimilarity from the R-package vegan [45]. We used the adonis R-function with 999 permutations to test for significant differences in community compositions between exclosures and control plots. Plant and arthropod communities separated by exclosures and control plots were visualized with non-metric multidimensional scaling (NMDS). All statistical data analyses were done in $\mathrm{R}$ version 3.4.1 [46].

\section{Results}

\subsection{Plant Diversity and Vegetation Structure}

Of 61 plant species in total, we found 47 plant species in deer exclosures and 51 in control plots. Deer exclusion had no significant effect on plant species richness (Figure 1a; $\chi^{2}{ }_{1,59}=2.06, p=0.152$ ) and diversity (Figure $1 b ; \chi^{2}{ }_{1,59}=0.21, p=0.648$ ). Species composition of plants was similar between exclosures and control plots (Figure 2; pseudo- $F_{1,59}=0.61$, $p=0.847)$. We found significant differences in the vegetation structure between deer exclosure and control plots: vegetation height (Figure $1 c ; \chi^{2}{ }_{1,63}=5.74, p=0.017$ ) and the heterogeneity of the vegetation (Figure $1 \mathrm{~d} ; \chi^{2} 1,63=12.38, p<0.001$ ) were significantly higher in deer exclosures compared to control plots.

\subsection{Herbivorous Insect and Spider Abundance, Richness, and Diversity}

In total, 2502 herbivorous insects were sampled in deer exclosures and 3720 in control plots. We found no differences in herbivorous insect abundance (Figure $3 a ; \chi^{2} 1,63=$ $1.28 p=0.258$ ), richness (Figure $3 b ; \chi^{2}{ }_{1,63}=0.15, p=0.700$ ) and diversity (Figure $3 c ; \chi^{2} 1,63=$ $0.29, p=0.592$ ) between exclosures and control plots. Herbivorous insect communities were similar between deer exclosures and control plots (Figure 4a; pseudo- $\mathrm{F}_{1,63}=0.46, p=0.753$ ). We collected 1214 spiders representing 20 families, 71 genera, and 105 species. Similar to the results regarding herbivorous insects, spider abundance (Figure $3 \mathrm{~d} ; \chi^{2}{ }_{1,63}=2.71$, $p=0.100$ ), richness (Figure 3e: $\chi^{2}{ }_{1,63}=1.32, p=0.252$ ), and diversity (Figure $3 f ; \chi^{2}{ }_{1,63}=0.32$, $p=0.573$ ) did not differ between exclosures and control plots. We found no differences in the composition of spider communities between exclosures and control plots (Figure $4 \mathrm{~b}$; pseudo- $\mathrm{F}_{1,63}=0.73, p=0.846$ ). 
(a)

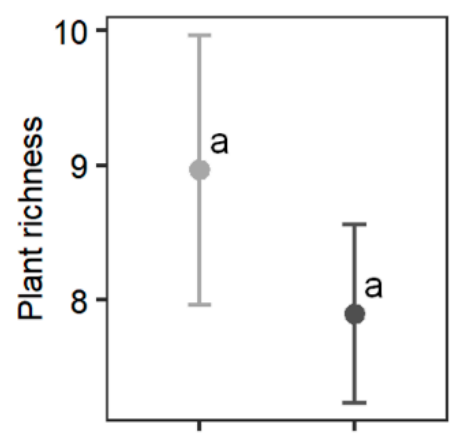

(c)

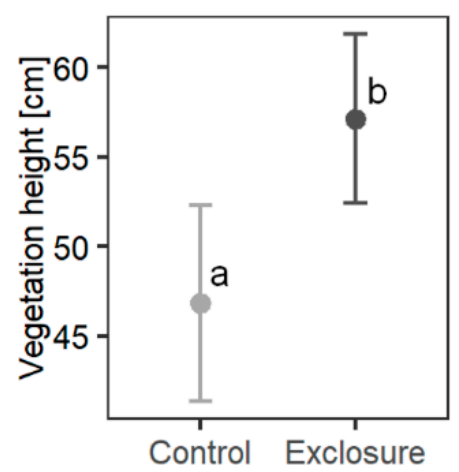

(b)

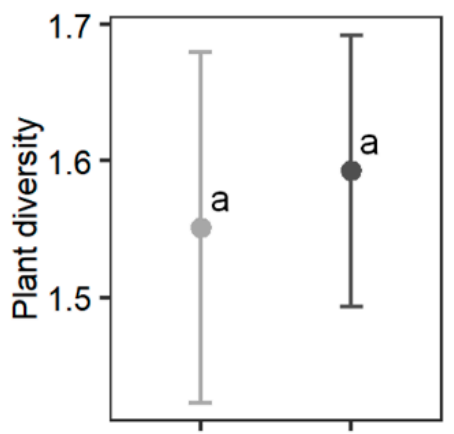

(d)

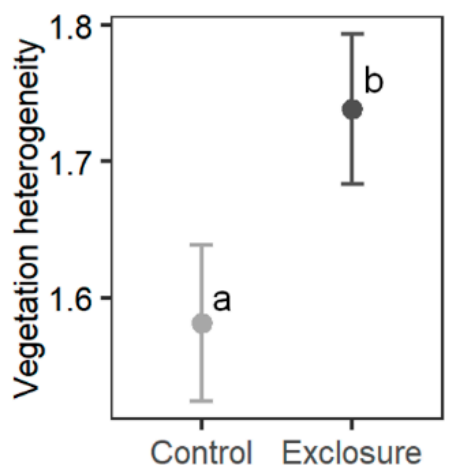

Figure 1. Depicts means ( \pm SE) of (a) plant species richness, (b) plant diversity, (c) vegetation height and (d) vegetation heterogeneity in control (light grey) and exclosure plots (dark grey). Statistical differences $(p<0.05)$ are indicated with different lowercase letters.

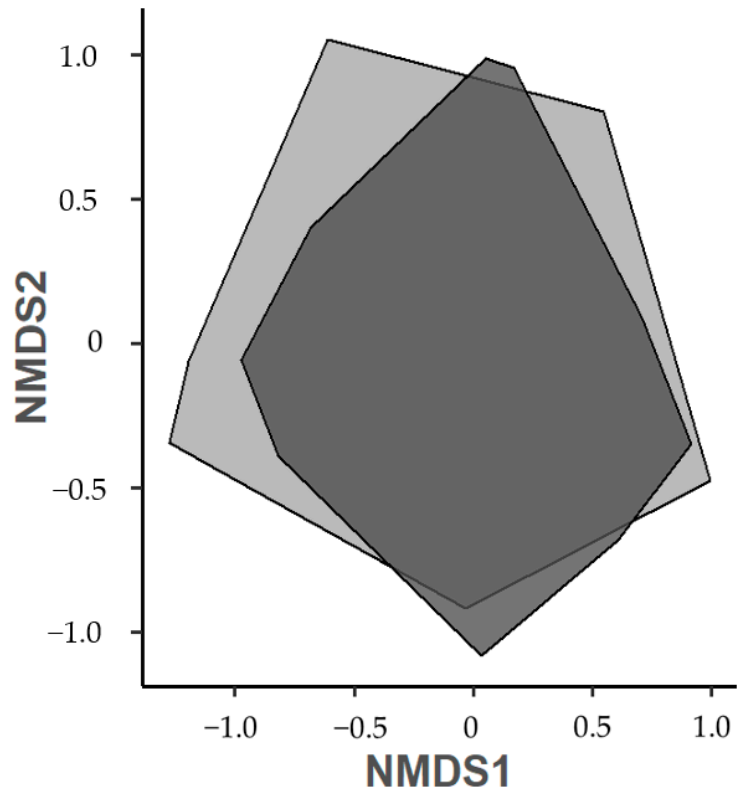

Figure 2. Shows the ordination of plant communities (non-metric multidimensional scaling) separated by control (light grey convex hulls) and exclosure plots (dark grey convex hulls). Plant communities did not differ between treatments. 
(a)

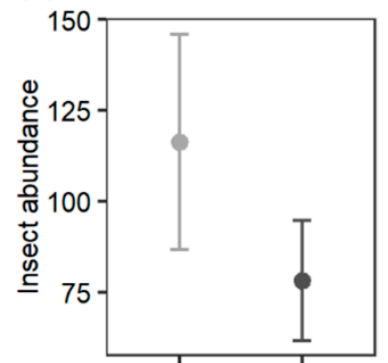

(d)

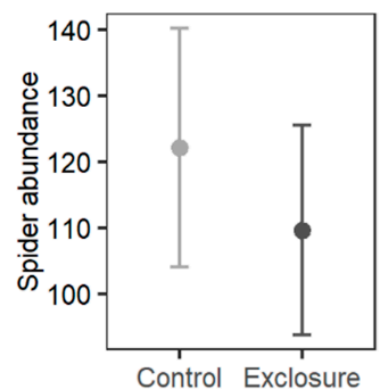

(b)

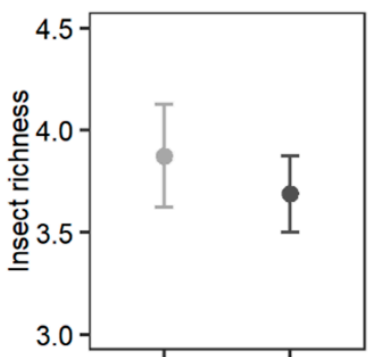

(e)

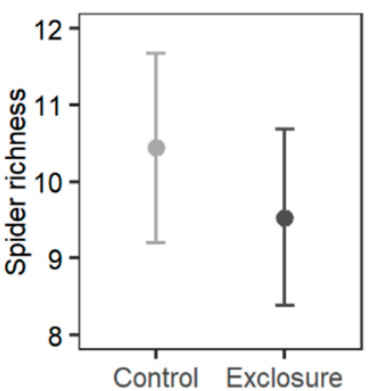

(c)

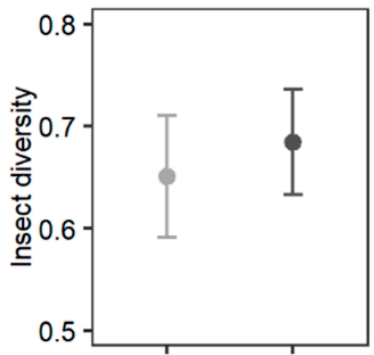

(f)

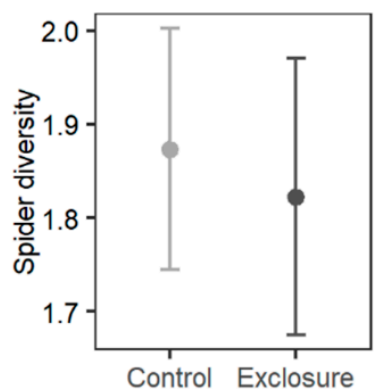

Figure 3. Shows mean $( \pm \mathrm{SE})$ abundance, richness, and diversity of herbivorous insects (a-c) and spiders (d-f) in control (light grey) and exclosure plots (dark grey). We found no statistical differences at the $\alpha<0.05$ level among the depicted parameters.

(a)

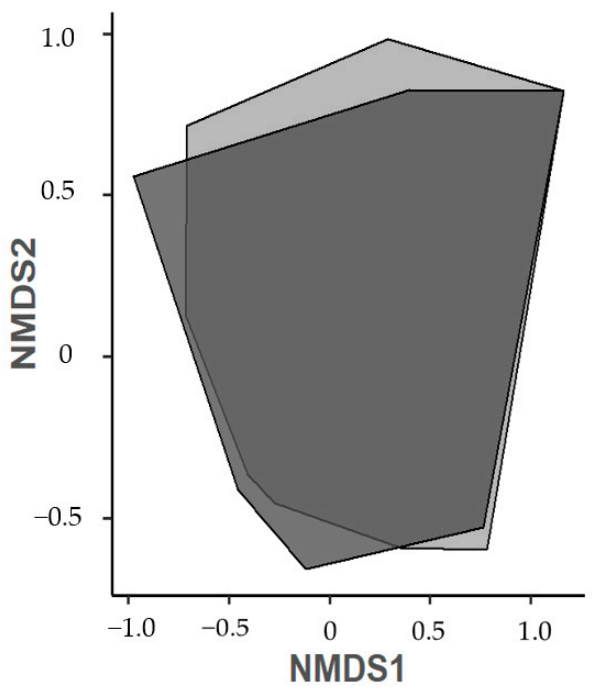

(b)

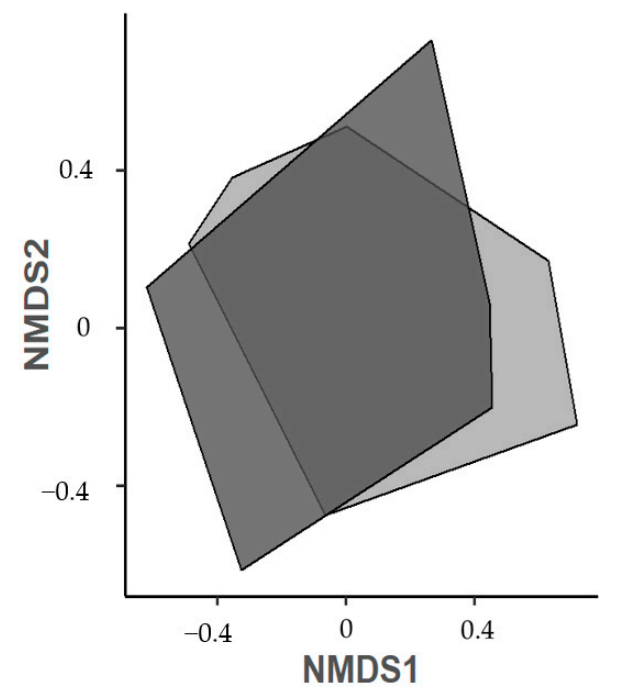

Figure 4. Shows the ordination of (a) insect and (b) spider communities (non-metric multidimensional scaling) separated by control (light grey convex hulls) and exclosure plots (dark grey convex hulls). Insect and spider communities did not differ between treatments.

\subsection{Spider Hunting Guilds}

3155 and 3511 spiders were collected in deer exclosures and control plots, respectively, belonging to 22 spider families (including juvenile individuals), which could be assigned to seven spider hunting guilds: Sheet-web weavers, space-web weaver (only the family Theridiidae), orb-web weavers, specialists (Mimetidae and Dysderidae), ambush hunters (Thomisidae), ground hunters and other hunters (including Erigoninae, Salticidae, Philo- 
dromidae among others). In deer exclosures, sheet-web weavers were marginally less abundant compared to control plots (Figure $5 ; \chi^{2}{ }_{1,63}=3.23, p=0.072$ ) and ambush hunters were significantly reduced in exclosures compared to control plots (Figure $5 ; \chi^{2}{ }_{1,63}=4.60$, $p=0.032$ ). In contrast, the abundance of ground hunters was higher in deer exclosures compared to control plots (Figure $5 ; \chi^{2}{ }_{1,63}=4.45, p=0.035$ ). We found no significant differences for space-web weavers $\left(\chi^{2}{ }_{1,63}=0.26, p=0.608\right)$, orb-web weavers $\left(\chi^{2}{ }_{1,63}=0.01\right.$, $p=0.923)$, specialists $\left(\chi^{2} 1,63=0.17, p=0.683\right)$ and other hunters $\left(\chi^{2}{ }_{1,63}=2.54, p=0.111\right)$ between exclosures and control plots.

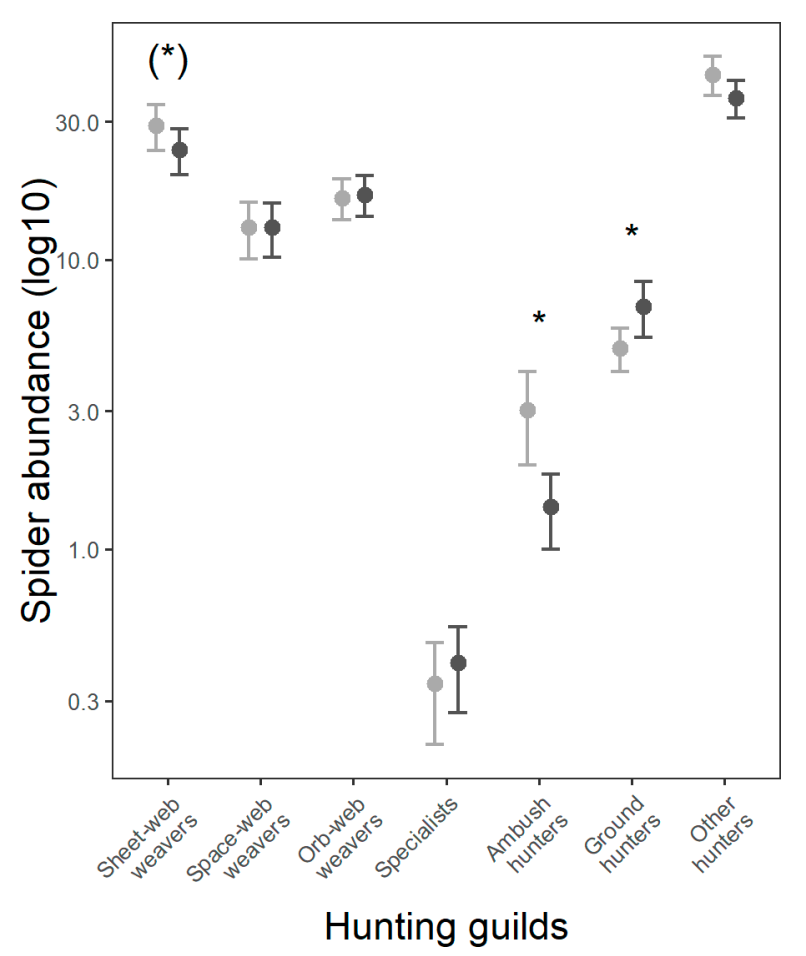

Figure 5. Shows mean ( \pm SE) abundance of juvenile and adult spiders separated by hunting guilds in control (light grey) and exclosure plots (dark grey). Please note that the y-axis is on a logarithmic scale. ${ }^{*} p<0.05 ;\left(^{*}\right) p<0.1$ indicate statistical differences.

\section{Discussion}

Although plant diversity and species composition were not affected by deer exclusion, vegetation height, and heterogeneity were higher in exclosures compared to control plots. Despite these structural changes in understory vegetation, we did not find differences in the diversity and community composition of herbivorous insects and spiders. However, we detected a shift among functional groups of spiders with fewer ambush hunters and sheet-web weavers in exclosures and more ground hunters in exclosures compared to control plots.

\subsection{Plant Diversity and Vegetation Structure}

Five years of deer exclusion did not reduce plant diversity and did not lead to a shift in plant species composition. This is in contrast with our expectations and with previous studies that reported a reduction in plant diversity and changes in plant community composition in the presence of ungulate herbivores $[22,47,48]$. Changes in plant diversity patterns in response to still moderate deer abundance likely require more time than five years to manifest themselves [21,22]. Exclosure plots after five years of deer exclusion might still be in recovery from browsing since exclosures do not instantly create conditions that would occur without browsing of large ungulate herbivores [48]. Shortly after the installation of exclosures, changes will mainly be influenced by the local species pool and seed banks, 
which might only change with chronic ungulate browsing [48]. Light availability in relation to canopy openness is another main driver of understory biodiversity $[49,50]$. Since our experiments were conducted in a mature forest, canopy openness is the same for the pair-wise plots and more time would be required until young trees would lead to different light conditions between exclosures and control plots. However, five to seven years of vertebrate herbivore exclusion were sufficient to change plant community composition from communities dominated by less preferred and more browsing-tolerant species to communities with more palatable plant species in open landscapes see [10]. A 16-year deer exclosure in an old-growth forest stand revealed changes in plant community composition but no changes in plant diversity [51]. Thus, it takes even more time until changes in plant community composition (i.e., turn-over and local extinction of plant species) result in a significant reduction of plant diversity. Indeed, the impact of large ungulate herbivores on plant species is multifaceted and can induce contrasting effects depending on ungulate herbivore species and densities, growth strategies and herbivore resistance of plants, and habitat productivity $[6,7,18,52]$. In our study system, the exclusion of roe deer and red deer likely requires more time until changes in plant communities and diversity become apparent.

Although we found no differences in plant communities and diversity, vegetation height, and vegetation heterogeneity were significantly higher in exclosures compared to control plots. This is in line with previous studies showing that deer affected the understory vegetation by reducing height and growth of plants through defoliation and browsing, which led to a more open and simplified vegetation structure [14,53]. In addition, the structure of the understory vegetation decreased in complexity with increasing time of deer presence [22]. In contrast to changes in plant diversity, deer effects on vegetation structure represent a short-term effect that occurs during every vegetation period. As such, we expect that deer keep modifying the structure of the understory vegetation and that these effects will accumulate with increasing duration of deer presence and will ultimately lead to the local extinction of less browsing-tolerant plant species.

\subsection{Arthropod Abundance and Diversity}

In our study, deer did not reduce the abundance of herbivorous insects and spiders. In contrast, previous studies in forest ecosystem reported negative effects of ungulate browsing on the abundance of herbivorous insects $[16,54]$ and spiders [33,55]. We suggest that competition between ungulate and insect herbivores for plant biomass was not strong enough to directly decrease insect abundance nor to indirectly reduce spider abundance via a decrease in prey availability. A meta-analysis by Foster et al. [18] revealed that most studies on ungulate browsing effects focused on areas with particularly high densities of ungulate herbivores, which in turn had mostly negative impacts on other animals. Due to the regulation of the ungulate population through active hunting, local deer densities at our study sites were likely not high enough to affect the abundance of arthropods at higher trophic levels.

Likewise, deer exclusion did not affect the diversity and community composition of herbivorous insects and spiders in our study. Negative effects of ungulate herbivores on arthropod diversity have been mainly attributed to changes in the plant species composition [18]. The lack of differences in the composition of herbivorous insect and spider communities between exclosures and control plots is likely due to lacking differences in plant community composition. To reveal differences in herbivorous insect communities a higher taxonomic resolution might be required because some specific insect families, genera or species might still have responded to ungulate browsing [56,57]. Although plant communities were unaffected by deer exclusion, changes in vegetation height and heterogeneity could have led to changes in spider species composition (i.e., via the availability of web-building site). However, taxonomic metrics (on species level) of spider diversity did not reveal differences between exclosures and control plots in our study. 


\subsection{Spider Hunting Guilds}

Although spider diversity did not differ between exclosures and control plots, we found differences in the abundance of spiders belonging to different functional groups. The response of spider hunting guilds to deer exclosures was contrasting and not as simple as expected: The abundance of space-web weavers and orb-web weavers did not differ between deer exclosures and control plots, whereas the abundance of sheet-web weavers tended to be lower in exclosures compared to control plots. Several authors postulated a negative relationship between ungulate herbivory and abundance of web-building spider guilds due to a decrease of habitat structure [16,58,59]. For example, Roberson et al. [16] found that the abundance and richness of web-building spiders was higher in exclosures compared to control plots, which they attributed to an increase in vegetation complexity likely increasing opportunities to anchor spider webs. Contrasting responses of webbuilding spiders to deer browsing among feeding guilds and habitats have been reported in other studies: sheet-web weavers had the tendency to respond differently to deer herbivory and changes in vegetation structure than space and orb-web weavers $[59,60]$. For example, sheet-web weavers are more strongly correlated with plant species richness compared to orb-web weavers [61].

Of the non-web-building spider hunting guilds, the abundance of ambush hunters was lower in exclosures, while the abundance of ground hunters was higher in exclosure plots. Unlike web-building spiders, ambush hunters do not weave webs but ambush prey from flowers or leaves in the litter or herb layer [62]. The prey of hunting spiders consists mainly of flying pollinating insects of the taxa Hymenoptera or Diptera [28]. The positive effect of deer on ambush hunters could be linked to higher abundances of flying prey. Vegetation cover and litter depth are important determinants for ground-living spiders [63]. Possibly, the positive response of the ground hunting guild was caused by a beneficial combination of vegetation cover and litter depth in exclosure plots. Deep litter has more interstitial space, which improves the availability of habitats for ground-living spiders within the litter [55,64]. Our results indicate that functional groups such as spider hunting guilds showed a more sensitive response to deer presence when compared with taxonomic biodiversity metrics and these responses are likely linked to changes in vegetation structure due to deer browsing.

\section{Conclusions}

Our comparison of deer exclosures and control plots in a managed forest ecosystem revealed no differences in diversity and community composition of plants, herbivorous insects, and spiders. Lacking differences between treatments are likely due to the age of the forest stand at the beginning of the experiment, the relatively short duration of the deer exclusion, and the still moderate deer densities in our forest. We suggest that deer density in Central Germany is not high enough to impair multitrophic understory biodiversity. More long-term studies including various arthropod groups at a high taxonomic resolution are required to obtain a deeper understanding of cascading effects of ungulate herbivores. Furthermore, it would be advantageous to quantify actual deer density (e.g., with camera traps) because local deer densities may vary a lot among control plots. This would help to characterize the relationship between ungulate density/browsing intensity and the abundance and diversity of other organisms. However, we found changes in the vegetation structure and spider hunting guilds, indicating that vegetation structure and spider hunting guilds are more sensitive to deer presence compared to taxonomic biodiversity metrics and can indicate deer impact on other organisms more immediately and already at low deer densities. Our study thus highlights the suitability of functional species groups such as spider hunting guilds to assess ecological impacts of ungulate herbivores. 
Author Contributions: Conceptualization, R.B., D.G.S. and N.F.; methodology, R.B., D.G.S., J.R., N.W., A.H. and A.G.; formal analysis, J.R. and R.B.; investigation, J.R., N.W., A.H. and A.G.; resources, N.F.; writing-original draft preparation, J.R. and R.B.; writing-review and editing, R.B., D.G.S. and N.F.; visualization, J.R. and R.B.; supervision, R.B., D.G.S. and N.F.; All authors have read and agreed to the published version of the manuscript.

Funding: This research received no external funding.

Institutional Review Board Statement: Not applicable.

Informed Consent Statement: Not applicable.

Data Availability Statement: The data presented in this study are available on request from the corresponding author. The study was conducted in cooperation with the Hessian administration of state forests (HessenForst). The provisioning of forestry related data is conditional on the consent by HessenForst.

Acknowledgments: We thank Eberhard Leicht (HessenForst), for the permission to use the study plots. We are grateful to Franziska Peter and Bernhard Eitzinger for the supervision of A.H. and A.G. during the parental leave of D.G.S. We thank three anonymous reviewers for valuable comments on earlier versions of the manuscript. The study was conformed to the Federal Nature Conservation Act (BNatSchG) given by the Regional Agency for Nature Conservation of Marburg-Biedenkopf $(\mathrm{P} / 23.00 / 2018-0013)$.

Conflicts of Interest: The authors declare no conflict of interest.

\section{References}

1. Forchhammer, M.; Stenseth, N.C.; Post, E.; Langvatn, R. Population dynamics of Norwegian red deer: Density-dependence and climatic variation. Proc. R. Soc. B Boil. Sci. 1998, 265, 341-350. [CrossRef]

2. Estes, J.A.; Terborgh, J.; Brashares, J.S.; Power, M.E.; Berger, J.; Bond, W.J.; Carpenter, S.R.; Essington, T.E.; Holt, R.D.; Jackson, J.B.C.; et al. Trophic Downgrading of Planet Earth. Science 2011, 333, 301-306. [CrossRef]

3. Ripple, W.J.; Estes, J.A.; Beschta, R.L.; Wilmers, C.C.; Ritchie, E.G.; Hebblewhite, M.; Berger, J.; Elmhagen, B.; Letnic, M.; Nelson, M.P.; et al. Status and Ecological Effects of the World's Largest Carnivores. Science 2014, 343, 1241484. [CrossRef]

4. Apollonio, M.; Andersen, R.; Putman, R. European Ungulates and Their Management in the 21st Century, 1st ed.; Cambridge Uni-versity Press: New York, NY, USA, 2010.

5. Burbaitè, L.; Csányi, S. Roe deer population and harvest changes in Europe. Estonian J. Ecol. 2009, 58, 169. [CrossRef]

6. Côté, S.D.; Rooney, T.P.; Tremblay, J.-P.; Dussault, C.; Waller, D.M. Ecological Impacts of Deer Overabundance. Annu. Rev. Ecol. Evol. Syst. 2004, 35, 113-147. [CrossRef]

7. Bernes, C.; Macura, B.; Jonsson, B.-G.; Junninen, K.; Müller, J.; Sandström, J.; Lõhmus, A.; Macdonald, E. Manipulating ungulate herbivory in temperate and boreal forests: Effects on vegetation and invertebrates. A systematic review. Environ. Evid. 2018, 7, 13. [CrossRef]

8. Hermy, M.; Verheyen, K. Legacies of the past in the present-day forest biodiversity: A review of past land-use effects on forest plant species composition and diversity. Ecol. Res. 2007, 22, 361-371. [CrossRef]

9. Huffman, D.; Laughlin, D.C.; Pearson, K.M.; Pandey, S. Effects of vertebrate herbivores and shrub characteristics on arthropod assemblages in a northern Arizona forest ecosystem. For. Ecol. Manag. 2009, 258, 616-625. [CrossRef]

10. Marquis, R.J. The role of herbivores in terrestrial trophic cascades. In Trophic Cascades. Predators, Prey, and the Changing Dy-namics of Nature; Terborgh, J., Estes, J.A., Eds.; Island Press: Washington, DC, USA, 2010; pp. 109-123.

11. Kuijper, D.P.; Cromsigt, J.P.; Jędrzejewska, B.; Miścicki, S.; Churski, M.; Jędrzejewski, W.; Kweczlich, I. Bottom-up versus top-down control of tree regeneration in the Białowieża Primeval Forest, Poland. J. Ecol. 2010, 98, 888-899. [CrossRef]

12. Huffman, D.W.; Moore, M.M. Ungulate Herbivory on Buckbrush in an Arizona Ponderosa Pine Forest. J. Range Manag. 2003, 56, 358. [CrossRef]

13. Bubnicki, J.W.; Churski, M.; Schmidt, K.; Diserens, T.A.; Kuijper, D.P. Linking spatial patterns of terrestrial herbivore community structure to trophic interactions. eLife 2019, 8, 44937. [CrossRef]

14. Van Klink, R.; Van Der Plas, F.; Van Noordwijk, C.G.E.; WallisDeVries, M.F.; Olff, H. Effects of large herbivores on grassland arthropod diversity. Biol. Rev. 2014, 90, 347-366. [CrossRef]

15. Gill, R.; Beardall, V. The impact of deer on woodlands: The effects of browsing and seed dispersal on vegetation structure and composition. For. An Int. J. For. Res. 2001, 74, 209-218. [CrossRef]

16. Stewart, A. The impact of deer on lowland woodland invertebrates: A review of the evidence and priorities for future research. For. An Int. J. For. Res. 2001, 74, 259-270. [CrossRef]

17. Suominen, O.; Danell, K. Effects of large herbivores on other fauna. In Large Herbivore Ecology, Ecosystem Dynamics and Conservation; Danell, K., Bergström, R., Duncan, P., Pastor, J., Eds.; Cambridge University Press: Cambridge, UK, 2006 ; pp. 383-412. 
18. Foster, C.N.; Barton, P.S.; Lindenmayer, D.B. Effects of large native herbivores on other animals. J. Appl. Ecol. 2014, 51, 929-938. [CrossRef]

19. Gómez, J.M.; González-Megías, A. Long-term effects of ungulates on phytophagous insects. Ecol. Entomol. 2007, 32, 229-234. [CrossRef]

20. Gómez, J.M.; González-Megías, A. Asymmetrical interactions between ungulates and phytophagous insects: Being different matters. Ecology 2002, 83, 203-211. [CrossRef]

21. Allombert, S.; Stockton, S.A.; Martin, J.-L. A Natural Experiment on the Impact of Overabundant Deer on Forest Invertebrates. Conserv. Biol. 2005, 19, 1917-1929. [CrossRef]

22. Martin, J.-L.; Stockton, S.A.; Allombert, S.; Gaston, A.J. Top-down and bottom-up consequences of unchecked ungulate browsing on plant and animal diversity in temperate forests: Lessons from a deer introduction. Biol. Invasions 2009, 12, 353-371. [CrossRef]

23. Hutchinson, G.E. Homage to Santa Rosalia or Why Are There So Many Kinds of Animals? Am. Nat. 2002, 93, 145-159. [CrossRef]

24. Southwood, T.R.E.; Brown, V.K.; Reader, P.M. The relationships of plant and insect diversities in succession. Biol. J. Linn. Soc. 1979, 12, 327-348. [CrossRef]

25. Strong, D.R.; Lawton, J.H.; Southwood, R. Insects on Plants. Community Patterns and Mechanisms; Blackwell Scientific Publications: Oxford, UK, 1984.

26. Halaj, J.; Ross, D.W.; Moldenke, A.R. Habitat structure and prey availability as predictors of the abundance and community organization of spiders in western Oregon forest canopies. J. Arachnol. 1998, 26, 203-220.

27. Ziesche, T.M.; Roth, M. Influence of environmental parameters on small-scale distribution of soil-dwelling spiders in forests: What makes the difference, tree species or microhabitat? For. Ecol. Manag. 2008, 255, 738-752. [CrossRef]

28. Bucher, R.; Entling, M.H. Contrasting effects of habitat fragmentation, population density, and prey availability on body condition of two orb-weaving spiders. Ecol. Ėntomol. 2011, 36, 680-685. [CrossRef]

29. Nyffeler, M. Prey selection of spiders in the field. J. Arachnol. 1999, 27, 317-324.

30. Katagiri, N.; Hijii, N. Effects of sika deer browsing on the arthropod communities on understory vegetation in a thinned Japanese cypress plantation. J. For. Res. 2015, 20, 347-356. [CrossRef]

31. Landsman, A.P.; Bowman, J.L. Discordant response of spider communities to forests disturbed by deer herbivory and changes in prey availability. Ecosphere 2017, 8, e01703. [CrossRef]

32. Meier, M.; Stöhr, D.; Walde, J.; Tasser, E. Influence of ungulates on the vegetation composition and diversity of mixed deciduous and coniferous mountain forest in Austria. Eur. J. Wildl. Res. 2017, 63, 29. [CrossRef]

33. Roberson, E.J.; Chips, M.J.; Carson, W.P.; Rooney, T.P. Deer herbivory reduces web-building spider abundance by simplifying forest vegetation structure. PeerJ 2016, 4, 2538. [CrossRef]

34. Bundesamt für Naturschutz (BfN). Vegetationskarte: Karte der Potentiellen Natürlichen Vegetation Deutschlands (PNV). 2004. Available online: http:/ / www.floraweb.de/vegetation/vegetationskarte.html (accessed on 8 November 2017).

35. Hessisches Landesamt für Naturschutz, Umwelt und Geologie (HLNUG). Umweltatlas Hessen: Die Naturräume Hessens und ihre Haupteinheiten. 2013. Available online: http://atlas.umwelt.hessen.de/servlet/Frame/atlas/naturschutz/naturraum/ texte/ngl-wb.htm (accessed on 8 November 2017).

36. Gerst, M.; Sundermann, M.; Westphal, P. Nachhaltigkeitsbericht für 2017; Landesbetrieb HessenForst: Kassel, Germany, 2018.

37. Kinser, A.; Koope, K.; Freiherr von Münchhausen, H. Die Rotwildverbreitung in Deutschland. AFZ-DerWald 2010, 5, 32-34.

38. Brook, A.J.; Woodcock, B.A.; Sinka, M.; Vanbergen, A.J. Experimental verification of suction sampler capture efficiency in grasslands of differing vegetation height and structure. J. Appl. Ecol. 2008, 45, 1357-1363. [CrossRef]

39. Stewart, A.J.A.; Wright, A.F. A new inexpensive suction apparatus for sampling arthropods in grassland. Ecol. Ėntomol. 1995, 20, 98-102. [CrossRef]

40. Cardoso, P.; Pekár, S.; Jocqué, R.; Coddington, J.A. Global Patterns of Guild Composition and Functional Diversity of Spiders. PLoS ONE 2011, 6, e21710. [CrossRef] [PubMed]

41. Bates, D.; Maechler, M.; Bolker, B.; Walker, S. Linear Mixed-Effects Models Using 'Eigen' and S4. Available online: https: / / cran.r-project.org/web/packages/lme4/lme4.pdf (accessed on 14 January 2018).

42. Zuur, A.F.; Ieno, E.N.; Elphick, C.S. A protocol for data exploration to avoid common statistical problems: Data exploration. Methods Ecol. Evol. 2010, 1, 3-14. [CrossRef]

43. Harrison, X.A. Using observation-level random effects to model overdispersion in count data in ecology and evolution. PeerJ 2014, 2, e616. [CrossRef] [PubMed]

44. Bolker, B.M.; Brooks, M.E.; Clark, C.; Geange, S.W.; Poulsen, J.R.; Stevens, M.H.H.; White, J.-S.S. Generalized linear mixed models: A practical guide for ecology and evolution. Trends Ecol. Evol. 2009, 24, 127-135. [CrossRef]

45. Oksanen, J.; Blanchet, F.G.; Friendly, M.; Kindt, R.; Legendre, P.; McGlinn, D.; Minchin, P.R.; O’Hara, R.B.; Simpson, G.L.; Solymos, P.; et al. Community Ecology Package. Available online: https://cran.r-project.org/web/packages/vegan/vegan.pdf (accessed on 14 January 2018).

46. R Core Team. R: A Language and Environment for Statistical Computing; R Foundation for Statistical Computing: Vienna, Austria, 2017.

47. Perea, R.; Girardello, M.; Miguel, A.S. Big game or big loss? High deer densities are threatening woody plant diversity and vegetation dynamics. Biodivers. Conserv. 2014, 23, 1303-1318. [CrossRef] 
48. Rooney, T.P.; Waller, D.M. Direct and indirect effects of white-tailed deer in forest ecosystems. For. Ecol. Manag. 2003, 181, 165-176. [CrossRef]

49. Finzi, A.C.; Canham, C.D. Sapling growth in response to light and nitrogen availability in a southern New England forest. For. Ecol. Manag. 2000, 131, 153-165. [CrossRef]

50. Košulič, O.; Michalko, R.; Hula, V. Impact of canopy openness on spider communities: Implications for conservation man-agement of formerly coppiced oak forests. PLoS ONE 2016, 11, e0148585. [CrossRef]

51. Rooney, T.P. High white-tailed deer densities benefit graminoids and contribute to biotic homogenization of forest ground-layer vegetation. Plant Ecol. 2009, 202, 103-111. [CrossRef]

52. Terborgh, J.; Estes, J.A. Trophic Cascades: Predators, Prey, and the Changing Dynamics of Nature; Island Press: Washington, DC, USA, 2010.

53. Rooney, T.P. Deer impacts on forest ecosystems: A North American perspective. For. An Int. J. For. Res. 2001, 74, 201-208. [CrossRef]

54. Den Herder, M.; Virtanen, R.; Roininen, H. Effects of reindeer browsing on tundra willow and its associated insect herbi-vores J. Appl. Ecol. 2004, 41, 870-879. [CrossRef]

55. Bressette, J.W.; Beck, H.; Beauchamp, V.B. Beyond the browse line: Complex cascade effects mediated by white-tailed deer. Oikos 2012, 121, 1749-1760. [CrossRef]

56. Barton, P.S.; Cunningham, S.A.; Lindenmayer, D.B.; Manning, A.D. The role of carrion in maintaining biodiversity and ecological processes in terrestrial ecosystems. Oecologia 2013, 171, 761-772. [CrossRef]

57. Jay-Robert, P.; Niogret, J.; Errouissi, F.; Labarussias, M.; Paoletti, É.; Luis, M.V.; Lumaret, J.-P. Relative efficiency of extensive grazing vs. wild ungulates management for dung beetle conservation in a heterogeneous landscape from Southern Europe (Scarabaeinae, Aphodiinae, Geotrupinae). Biol. Conserv. 2008, 141, 2879-2887. [CrossRef]

58. Miyashita, T.; Takada, M.; Shimazaki, A. Indirect effects of herbivory by deer reduce abundance and species richness of web spiders. Écoscience 2004, 11, 74-79. [CrossRef]

59. Takada, M.; Baba, Y.G.; Yanagi, Y.; Terada, S.; Miyashita, T. Contrasting Responses of Web-Building Spiders to Deer Browsing Among Habitats and Feeding Guilds. Environ. Èntomol. 2008, 37, 938-946. [CrossRef]

60. Rypstra, A.L. The importance of food and space in limiting web-spider densities; a test using field enclosures. Oecologia 1983, 59, 312-316. [CrossRef]

61. Bucher, R.; Nickel, H.; Kaib, S.; Will, M.; Carchi, J.; Farwig, N.; Schabo, D.G. Birds and plants as indicators of arthropod spe-cies richness in temperate farmland. Ecol. Indic. 2019, 103, 272-279. [CrossRef]

62. Roberts, M.J. Collins Field Guide: Spiders of Britain and Northern Europe; HarperCollins Publishers Ltd.: London, UK, 1995.

63. Schuldt, A.; Fahrenholz, N.; Brauns, M.; Migge-Kleian, S.; Platner, C.; Schaefer, M. Communities of ground-living spiders in deciduous forests: Does tree species diversity matter? Biodivers. Conserv. 2008, 17, 1267-1284. [CrossRef]

64. Uetz, G.W. Habitat structure and spider foraging. In Habitat Structure: The Physical Arrangement of Objects in Space; Bell, S.S., McCoy, E.D., Mushinsky, H.R., Eds.; Chapman \& Hall: London, UK, 1991; pp. 325-348. 